\title{
The Role of Entrepreneurial Orientation and Modularity for Business Model Innovation in Service Companies
}

\author{
Ricarda B. Bouncken* and Christian Lehmann \\ University of Bayreuth \\ Prieserstrasse 2, 95440 Bayreuth, Germany \\ E-mail: Bouncken@uni-bayreuth.de \\ E-mail: Christian.lehmann@uni-bayreuth.de \\ *Corresponding author \\ Katharina Fellnhofer \\ New Design University \\ Privatuniversität St. Pölten \\ Mariazeller Straße 97a, 3100 Sankt Pölten, Austria \\ E-mail: katharina.fellnhofer@ndu.ac.at
}

\section{Bibliographical notes:}

Ricarda Bouncken holds the Chair of Strategic Management and Organization at the University of Bayreuth. She has published more than 200 peer-reviewed articles and books. Her research focuses on innovation alliances, business model innovation, and coopetition alliances.

Christian Lehmann is Senior Lecturer for Business Models and Entrepreneurship at the University of Bayreuth. He focuses on the understanding and development of business models in service firms and is interested in how digitalisation changes the nature of work.

Katharina Fellnhofer is lecturing at the Chair of Entrepreneurship and Innovation at the New Design University, Austria. She holds a Ph.D. in entrepreneurship from the University of Innsbruck, Austria. 


\begin{abstract}
The phenomenon of business model innovation (BMI) is taking up speed in researchers' attention. Specifically service firms find it difficult to protect their intellectual property and need dynamic capabilities to invent and launch their new business models. This study on service firms' BMI applies the Dynamic Capability View (DCV) to understand how two capabilities, entrepreneurial orientation (EO) and modularity produce BMI. These two capabilities consider two sides of BMI. BMI relates to opportunity-seeking behavior, creating new values and opportunity exploitation, that then allows monetizing and capturing value. In this respect, BMI takes advantage of the two dynamic capabilities: EO and modularity. The results of our study of 299 international service firms show that EO and modularity trigger BMI, and that EO is especially favourable for BMI in the context of high environmental uncertainty.
\end{abstract}

Keywords: business model innovation, dynamic capabilities, entrepreneurial orientation, modularity

\title{
1. Introduction
}

Business model innovation (BMI), first mentioned by Papinniemi (1999), receives flourishing attention by researchers (Srinivasan, 2011; Amit and Zott, 2012; Euchner and Ganguly, 2014). BMI incorporates change and renewal through the commercialization of ground-breaking ideas, technologies, and new business concepts (Chesbrough, 2010; Zott et al., 2011). Previous research, often focused on internet businesses, developed the important characteristics of BMI: value-generation processes, value creation, proposition, and capture (ElMaraghy, 2005; Sánchez and Ricart, 2010).

In the literature on BMI, internet firms and the manufacturing industry dominate. The focus of our study lies on service firms that have fewer possibilities to protect their innovation by intellectual property rights and thus are constantly in need of dynamic capabilities to search for new business ideas (Vargo and Lusch, 2008; Voss and Hsuan, 2009).

The novel value generation, value creation, value proposition, and value capture of BMI are at the core of new business ideas and ventures into new territories. Yet, it remains unclear what dynamic capabilities underlie the process of value generation, value proposition, and value capture (Osterwalder et al., 2005; Schneider and Spieth, 2013). This is especially important for 
service firms which are unable to store and to standardize their offering due to the immateriality of services and the simultaneity of production and consumption (Lovelock and Gummesson, 2004; Grönroos and Ojasalo, 2004).

This paper aims to understand dynamic capabilities that determine BMI in service firms. We selected two capabilities: As venturing into new territory requires risk taking, innovativeness, and proactivity, we focus on EO (Schindehutte et al., 2008; Guo et al., 2013; Habtay and Holmén, 2014); second, service firms can select specific service processes as modularized process patterns. These modular service patterns can create new service offerings or recombine service components to propose and capture value. The modularity of product components has already shown strong improvements in efficiency and innovation, in production management, and in product innovation management (Sanchez and Mahoney, 1996; Worren et al., 2002; Bouncken et al., 2014). Yet, this concept is new to service research. We assume that modularization enables strong gains for service firms and shapes a dynamic capability for their BMI. Thus, we selected modularity as a second capability. We argue that EO and modularity are important in situations of high uncertainty, where service firms have to change and/or adapt their business models.

In essence, this paper considers EO and modularity as dynamic capabilities in service firms and analyses how they influence BMI in cases of high uncertainty. Herein we aim to contribute to the new body of research on BMI, which is still fragmented with weak theoretic underpinnings (Vermeulen, 2013; Chen et al., 2015), and to service research, which has not yet embraced the ideas of BMI even though it drives service venturing and service strategy. Further, we highlight two important antecedents to BMI and link the research on business models with strategic management.

Our theoretical part starts with an explanation of business models and BMI. We continue with dynamic capabilities which are subsequently linked to BMI. Thereafter, we present our sample, the method, and our results. The paper concludes with a discussion of our findings and of the contribution our study makes to theory building. 


\section{THEORY}

\subsection{Business model innovation}

Recently, business models received great attention, with more than 1177 articles in peer-reviewed journals (Amit and Zott, 2001; Al-Debei and Avison, 2010, Lecocq et al., 2010; Lambert and Davidson, 2013). Business models are a "set of capabilities that is configured to enable value creation consistent with either economic or social strategic objectives" (Seelos and Mair, 2007). Commonly, a business model defines a large variety of a firm's characteristics, resources, and decision variables, which convert opportunities into value creation and capture (Seddon et al., 2004; O'Connor and Yamin, 2011; Zott et al., 2011). Value creation follows no linear or simple method, but rather more complex and interconnected relationships among multiple actors (Zott et al., 2011).

Triggered by internet business and its innovative opportunities for business (Markides, 2013; Spieth et al., 2014), business models have increasingly embraced innovation (Chesbrough and Rosenbloom, 2002; Chesbrough, 2010; Teece, 2010; Onetti et al., 2012; Lambert and Davidson, 2013). BMI concerns "[a] process of designing a new, or modifying the firm's extant activity system" (Zott and Amit, 2010).

Innovating a firm's business model involves adding and linking novel activities through integration at different levels and in new ways (Witell and Löfgren, 2013). BMI aims at consciously renewing a firm's core business rather than concentrating on particular product or service innovations (Amit and Zott, 2010). It focuses on the exploitation of firms' core competencies (Hamel and Prahalad, 1993) and the creation of alliances (Mowery et al., 1996). BMI uses trends - e.g. increasing customer magnitude (Teece, 2010), service orientation (Gremyr et al., 2010; Nair et al., 2013), and new forms of innovation such as open innovation (Rajala et al., 2012; Huang et al., 2013).

Based on Mitchell and Coles' (2004) link between continuing BMI and sports, uncertainty or "the unknown" appears to be a central challenge to the successful implementing of innovations and specifically business model innovations (Andries and Debackere, 2013). Originally phenomenon-oriented, some researchers explain BMI on the basis of positive effects on a firm's performance and under environmental dynamism. BMI also corresponds to dynamic capabilities (Heij et al., 2014). Informal exchanges in the organization, mutual involvement, and organizational justice, as well as 
cultural aspects such as innovation orientation, are dynamic capabilities driving BMI (Bouncken and Koch, 2007; Bouncken, 2007; Santos et al., 2009). BMI contributes to improved environmental adaptation and long-term competitive advantage while facilitating and utilising the firm's entrepreneurial capabilities (Schindehutte et al., 2008; Habtay and Holmén, 2014). Research requires further understanding of underlying capabilities, particularly of how to constantly renew a firm's existent business model. For service companies, BMI especially consists of integrating customers in the process of value creation (Clauß et al., 2014). Due to the high level of customer integration, BMI needs to be more comprehensive in service firms than in manufacturing companies in order to increase service quality and profitability (Kindström, 2010).

\subsection{Dynamic Capability View (DCV)}

The DCV treats organizations as bundles of resources to achieve competitive advantages (Teece and Augier, 2009). Teece et al. (1997: 516) define 'dynamic capabilities as the firm's ability to integrate, build, and reconfigure internal and external competences to address rapidly changing environments'. Dynamic capabilities develop over time rather than being externally acquired (Teece et al., 1997; Teece, 2007) and rely on deep organizational structures such as innovation orientation (Siguaw et al., 2006; Bouncken et al., 2007; Kearney et al., 2014). They also have a strong impact on firm performance (Zott, 2003; Vorhies et al., 2007; Drnevich and Kriauciunas, 2011; Guangping et al., 2013; Makkonen et al., 2014).

Based on Barreto's (2010) definitions and descriptions of dynamic capabilities, we first regroup definitions and major papers referring to them. Second, we highlight the key factors and assumptions of each stream of definition(s). DCV stresses that a firm constantly needs to adapt, improve, and recombine its capabilities and their sources to stay competitive. As such, dynamic capabilities can act as drivers of BMI (Bock et al., 2012; Singh et al., 2013; Roaldsen, 2014).

Previous studies also assume that the performance of a business model depends on components (Aspara et al., 2010; Heij et al., 2014) which are rooted in internally or externally oriented capabilities (Dixon et al., 2014). The literature on (product) innovation processes distinguishes between firms' activities to explore new ideas, concepts, or business models, and their capability to exploit those ideas and to realise additional revenues (Bucherer 
et al., 2012). Table 1 presents our literature review and links dynamic capabilities to BMI.

INSERT TABLE 1 ABOUT HERE

Thus, the two different dynamic capabilities may be perceived as antecedents of BMI, as they facilitate the recognition of new opportunities (EO) and enable firms to capture additional values through the modularisation of its products and services.

\subsection{The twofold nature of BMI}

BMI relates opportunity seeking to the creation of new values and opportunity-exploitation to monetise and capture value (Andries and Debackere, 2013). Drawing on Tushman's and O'Reilly's (1996) notion of ambidexterity, we conceive of EO and modularity as two distinct forms of organizational capabilities to foster change and renewal in uncertain market conditions.

With regard to exploration, firms need to be open and risk-affine in order to screen their environment and perceive opportunities (Ellis et al., 2014). To exploit new ideas, firms have to rely on tools to implement new products and/or market-related features into their range of products without risking cannibalism or obsolescence of the existing business model. This may be achieved, for instance, through modularization as a recombination of existing value elements with new features that influence value generation (Huang et al., 2012). EO and modularization will specifically account for BMI under strong uncertainties as typical for dynamic capabilities (Sánchez and Ricart, 2010; Bock et al., 2012; Cautela et al., 2014; Roaldsen, 2014).

\section{Entrepreneurial Orientation (EO)}

According to Kraus (2013), the best-researched dimensions of EO are risktaking (Keh et al., 2002; Morris et al., 2008), proactivity (Rauch et al., 2009), and innovativeness (Lumpkin and Dess, 1996; Morris et al., 2008; Rowley et 
al., 2011; Van Riel et al., 2011). Scholars have argued that inertia is one of the core barriers to BMI (Chesbrough, 2010). In contrast, experimentation with technologies, idea generation, and collaboration drives BMI, resulting in value generation (McGrath, 2010). A firm's EO and reconfiguration capabilities influence performance (Jantunen et al., 2005; Irava and Moores, 2010). This confirms Teece (2007), who puts forward that organizations need a risk-taking behaviour to successfully reconfigure their business. Thus, EO serves as a dynamic capability that drives the value generation and value proposition of a firm's business model. To put it differently: EO is a major trigger of BMI. EO has often been associated with young, rather small firms which are versatile towards changes in market structure and environmental dynamism (Hannan and Freeman, 1984). Their lack of established structures lowers the risk of organizational inertia. As we focus on young and rather small service firms, the role of EO for BMI becomes even more apparent.

Research also indicates that EO has strong relations to uncertainty (Kraus et al., 2012), which in turn is strongly linked to innovation (York and Venkataraman, 2010). Thus, we argue that uncertainty drives the importance of EO as a dynamic capability for BMI. The innovative, risk-taking attitude of EO drives the creation of new ideas and EO will then also drive BMI.

H1: Influenced by increasing technological uncertainty, EO is a driver of business model innovation.

\section{Modularity}

Modularity implies the decomposition of a complex system into modules (Schilling, 2000; Conrad et al., 2014). A modular system is composed of units which are designed independently and are related through interfaces (Campagnolo and Camuffo, 2010). Each module covers a specific, but limited array of features and functions (Cavin and Lohse, 2014). The final product or service is developed by combining different customer or need-specific modules. Modularity allows for efficient management of complexity of multifaceted processes (Ethiraj and Levinthal, 2004; Ro et al., 2007; Tsvetkova and Gustafsson, 2012). Research on modularity spans product modularization (Lau and Yam, 2005; Scannella, 2010; Persson and Åhlström, 2013), business networks (van Liere et al., 2004; Van Liere and Koppius, 2007), knowledge management (Sanchez and Mahoney, 1996; Ravishankar and Pan, 2013), and innovation (Ethiraj and Levinthal, 2004; Ethiraj et al., 
2008; Voss and Hsuan, 2009; Ozman, 2011). Modularity is a central design principle of the product architecture and enables strategic and operational flexibility (Tsvetkova and Gustafsson, 2012).

Pisano and Teece (2007) state that modularity improves the value capture from innovation. Drivers behind modularity are the creation of variety, the reduction of complexity, and the balance of customization and standardization (Miller and Elgard, 1998; Blecker and Abdelkafi, 2006; Mikkola, 2007). Further, modularity is a vehicle for reconfiguring a firm's asset structure (Sirmon et al., 2007). It can be beneficial in dealing with growing complexity and environmental dynamism (Kodama, 2004). Thus, it is a suitable means for coping with uncertainties.

Modularity is a key principle of the architecture of service firms (Voss and Hsuan, 2009). Services are bundles of performance promises. Their production inescapably integrates the customer, who becomes a co-creator (Zeithaml et al., 1985). Take the following simple example of modularity in service processes: A client in a restaurant chooses some food from the menu. The owner of the restaurant provides the range of accessible food but the choice is made by the client. After the client has selected the components (or modules) of his meal, the staff prepares and serves the menu. The case of the restaurant illustrates the role modularity has for services: modularity serves to satisfy distinct customer needs; it allows diversification and provides flexibility. The customer's possibility to choose lowers the service firm's risk of failing to provide what the customer wants (Weng, 1999). Thus modularity makes it possible to develop and offer new services and is a suited means for shaping existing business models. Modularity further allows the recombination of service patterns and packages to develop new offerings and business models.

This stresses the importance that modularization has for service firms in an environment of higher uncertainty for BMI value generation and capture through reconfiguration of value-chain elements (Sánchez and Ricart, 2010; Amit and Zott, 2012; Simmons et al., 2013; Bouncken et al., 2015). Parente, Baack, and Hahn (2011) further point out that modularization drives the efficiency in the innovation process. We assume that modularity is a dynamic capability for developing new service products, because it allows the capture of value from new patterns and re-combinations of service-product components that emerge in a multifaceted and complex environment. Thus, we perceive modularity as a strategic means for creating a "built-in 
flexibility" (ElMaraghy, 2005) which is suitable for coping with uncertainty and fostering innovation of the business model.

H2: Influenced by increasing technological uncertainty, modularity is a driver of business model innovation.

\section{Complementarity of EO and Modularity}

Prior research recognized that firms achieve greater performance when they implement "classical" business innovations such as value creation, proposition, and capture by radical innovation at every level of the business model. Overall, BMI can inspire changes during a process of "business model reconfiguration" of only one or two domains of the business model. Although research still lacks a clear definition of the ambiguous and multifaceted concept of BMI (Amit and Zott, 2001; Al-Debei and Avison, 2010; Lecocq et al., 2010; Lambert and Davidson, 2013), we assume that radically innovative BMIs are subject to uncertainty and benefit from a combination of both dynamic capabilities discussed above.

EO includes proactive, risk-averse, and creativity-oriented thinking and behaviour (Vij and Bedi, 2012). Nonetheless, modularity requires fine-grained analyses, precise planning, and the implementation of formal architectures that consist of highly compatible business, process, or service-process modules that can be recombined without much change to another module. Whereas EO helps to explore new opportunities (Coulthard, 2007), modularity serves to exploit flexible product architectures in stages being near to the market (Sanchez and Mahoney, 1996; Buenstorf, 2005). The combination of EO and modularity by service firms has additional positive effects for BMI. The causal complexity inherent in one of the DCs increases with a further social and causal interaction of the DCs and allows the development of imitation barriers (Ethiraj and Levinthal, 2004; Hipp and Bouncken, 2009), creating a sustained competitive advantage (López, 2005). Thus, we argue that the capability to explore new opportunities with risk-affinity and innovativeness (EO) and the capability to reconfigure resources and existing capabilities (modularization) enables a firm to simultaneously explore and exploit new opportunities (O'Reilly and Tushman, 2009). This, in turn, will lead to a surplus of BMI as a precondition for competitive performance. 
H3: Both modularity and entrepreneurial orientation enfold an additional joint effect on business model innovation.

The research framework, the hypotheses, and the suggested directions of the effects are summarized in Figure 1.

INSERT FIGURE 1 ABOUT HERE

\section{METHODOLOGY}

\subsection{Sample characteristics and data collection}

Our sample consists of 299 German service firms. The data were collected at two different trade fairs in 2013 and 2014. Potential respondents were chosen randomly. We then made an appointment with sales representatives or with a member of each firm's general management in preparation. Second, informants were contacted about four weeks following each trade fair. While first informants received a paper-and-pencil version of the questionnaire, data from second informants were gathered by computer-assisted telephone interviews (CATIs).

A total of 360 questionnaires were returned to us. After deleting outliers and duplicates, we removed all datasets with missing values on our dependent variable BMI. Finally, we had 299 evaluable questionnaires. We then analysed the dataset for missing values and found that there were no systematic missing data. Nevertheless, we account for 11.7 per cent of randomly missing values on our independent variables (or 35 cases, 264 remaining cases). Table 2 presents the descriptive statistics of our sample.

INSERT TABLE 2 ABOUT HERE 
We contacted exclusively B2B service firms offering business services such as IT, engineering, or consulting. The vast majority of the firms surveyed are SMEs: 82 per cent of all firms have fewer than 200 employees; every second firm has fewer than 50 employees. The average annual turnover is 33.9 million euros (median: 8.0 million euros), and the average service firm achieves a rate of return (EBITDA) of 17.5 per cent (median: 14.0 per cent).

Table 2 further shows that nearly three of four respondents ( 74 per cent) belong to top, upper, and middle management. The average tenure of the surveyed managers is 6.8 years (median: 4.2 years). More than 80 per cent ( 84 per cent or 250 persons) are male.

The high level of internationality is a unique feature of our sample. More than 60 per cent (188 firms) are located outside Germany; nearly every third firm (31 per cent or 95 companies) comes from outside the European Union. The top five countries are Germany (112 firms), Italy (33 firms), China (30 firms), Turkey (15 firms), and the United States (12 firms). Table 3 summarizes the firms' origin. The high level of internationality is associated with a relatively high share of exports: the average service firm in our sample realizes 44 per cent (median: 43 per cent) of its turnover abroad.

\section{INSERT TABLE 3 ABOUT HERE}

\subsection{Measurement}

The variables in our study were measured on five-point Likert-type scales ( $1=$ "strongly disagree", $5=$ "strongly agree"). The scales were adopted from previously published articles, translated from English into German, and then translated back to check whether meaning and comprehensibility were well maintained.

Entrepreneurial orientation was measured as a second-order construct, consisting of three dimensions: risk-taking, proactivity, and innovativeness, following the approach of Eggers et al. (2013). The first-order constructs consisted of three items each, such as "We encourage people in our company to take risks with new ideas." (risk-taking), "We consistently look for new business opportunities." (proactivity), or "We consider ourselves as an 
innovative company." (innovativeness). Thresholds were acceptable for statistical criteria on the first-order level. Our self-developed scale to measure modularity consisted of three items and focused on modular products (Sanchez and Mahoney, 1996). We asked for the amount and functionality of modules and interfaces, and the general function of modularity on the product architecture. The scale was self-developed and adapted from ten to three items following a pre-test.

Technological uncertainty was measured with three items from Lewis' (2002) ten-item scale. We chose the three items with the highest factor loadings from this scale and asked, for example, for the level of "technological feasibility" of changes to existing products.

BMI refers to changes in how a firm creates, proposes, or captures value. The multi-dimensional construct was captured by an existing scale from innovation management (Bouncken et al., 2007) which was enlarged by two items regarding the market and the value added for customers. Overall, we captured all three dimensions of BMI with at least one item.

Competitive performance is a three-item scale measuring the performance of a firm compared with its competitors regarding sales volume, market share, and profitability (margin). The scale was taken from Venkatraman and Ramanujam (1986).

We used firm size as a control variable to account for the influence of a firm's size on our independent variables. The result of a confirmatory factor analysis is shown in Appendix 1.

\subsection{Analysis}

We used the co-variance-based structural equation modelling approach (SEM) in the software package Mplus 6 (Muthén and Muthén, 2012) to test our hypotheses. Compared with multivariate regression analysis, SEM has three major advantages: first, SEM uses latent (or unobserved) variables which account for the influence of residuals or measurement errors (Bagozzi and Yi, 2012); second, SEM is capable of incorporating latent variables as well as manifest variables simultaneously (Byrne, 2012); and third, SEM allows for path modeling which is of great importance for social sciences.

In a first step we validated our measurement model via a confirmatory factor analysis (CFA) with maximum likelihood estimation. The CFA resulted in an acceptable to good overall model fit: Despite a significant chi-square test $(\mathrm{t}=1.590 * * *)$, the stricter and more appropriate fit-indices were all below their 
thresholds $(\mathrm{CFI}=.934, \mathrm{RMSEA}=.044, \mathrm{SRMR}=.068)$. On the construct-level we scrutinized the validity and reliability for each latent variable. Construct validity of the latent variables, expressed by the standardized factor loading of each indicator item, exceeded the minimum threshold of .5 (Hair et al., 2010) for all variables. To assess the convergent validity of our latent variables we applied Cronbach's $\alpha$ (Cronbach, 1951) and the average variance extracted. All constructs exceed the minimum thresholds of .7 and .5, respectively (Nunnally, 1978; Fornell and Larcker, 1981). We assessed the reliability of our latent variables on the item-level and on the construct-level. Indicator reliabilities are greater than .4 for all indicator items except one from our BMI-scale, which slightly missed the threshold of .4 (Bagozzi et al., 2004). But as the BMI-scale, like all other scales, showed a good reliability on the construct level with composite reliabilities greater than .6 (Bagozzi, 1981), we decided to keep this item in our measurement model. Finally, we tested whether the constructs met the Fornell-Larcker-criterion indicating that each latent variable's variance is better explained by its indicator items than by other constructs (Fornell and Larcker, 1981). None of our variables violated this assumption, which is expressed by a variable's ratio of the variance explained and its maximum correlation with other (latent) variables smaller or equal to one. Appendix 2 presents the results of our confirmatory factor analysis.

To cope with non-response bias we offered each firm a report of the study's results. We hoped to convince some initial non-respondents to support our study by providing this incentive to the participants. As we used single informants for our independent measures, common-method bias might have occurred. To account for this statistical problem we followed the recommendations of Podsakoff et al. (2003) using Harman's single-factor test. The computed factor explained less than 25 per cent $(24$ per cent) of the variance of all variables used in this study. Additionally, we distributed a short questionnaire containing our most important dependent variables (e.g. firm performance) and some questions about the firms' structure to second informants from the same company. We used first informants' data for our independent variables EO, modularity, and uncertainty. Data from second informants were chosen for our dependent variables BMI and competitive performance. We also analysed the correlations between first and second informants' responses and found medium to high correlations for every item (e.g. firm size $.963^{* * *}$ ). Overall, common-method bias does not seem to be an issue in our data. 
Our hypotheses were tested with two different SEMs. Our first model comprised hypotheses one and two and was compiled as a path model with indirect effects to test our mediation hypotheses. The model revealed good overall fit (cf. table 3). The second model contained the moderation effect in hypothesis three. We tested whether the interaction term of the two capabilities EO and modularity yields to a significant increase in the explained variance of our dependent variable BMI (Muthén and Muthén, 2012). All results are presented below.

\section{RESULTS}

The correlation matrix of the constructs shows the positive relation between competitive performance and business model innovation. Although not explicitly hypothesized, we find that competitive performance is positively associated to BMI, EO, and modularity (cf. table 4). We also find a medium correlation between EO and modularity $(\mathrm{r}=.489 * * *)$, indicating that deployment of the explorative EO is accompanied by exploitative modularity. Interestingly, the control variable 'firm size' does not correlate significantly with any other variable of our model. We can therefore assume that BMI, EO, or modularity is not a matter of size.

INSERT TABLE 4 ABOUT HERE

In hypothesis 1 we scrutinized the influence of entrepreneurial orientation on BMI with regard to uncertainty. Results show that both hypotheses are supported: EO exerts a strong direct influence on BMI $(\beta=.412 * * *)$. Additionally, we found a significant indirect effect of uncertainty on BMI via EO $\left(\beta=.105^{* *}\right)$. We thus assume that EO is an important driver of BMI, especially when the environment is turbulent.

Hypothesis 2 supposed an influence of modularity on BMI. As for EO, we examined in detail the direct influence of modularity on BMI and the indirect effect of uncertainty on BMI via modularity. Again, we find support for the first hypothesis, supposing a direct influence of modularity on BMI. The standardized path coefficient yields $.250 * *$. But we were unable to prove 
an indirect effect of uncertainty on BMI in $\mathrm{H} 2 \mathrm{~b}$ ( $\beta=.017$ n.s.). Though, modularity is a trigger for BMI, but independent of technological uncertainty (cf. table 5). Figure 2 depicts the regression weights of our research model.

INSERT FIGURE 2 ABOUT HERE

Hypothesis 3 assumed a positive interaction effect of entrepreneurial orientation and modularity on BMI. This assumption was backed by the notion of ambidexterity. Despite theoretical support the interaction effect was insignificant ( $\beta=.054$, n.s.). Our data do not support hypothesis 3 .

INSERT TABLE 5 ABOUT HERE

Finally, to control for country effects we calculated two distinct models. In the first, German-only model with size as control variable we found a slightly smaller direct effect of EO and modularity on BMI $(\beta=.27 * * *$ for EO and $\beta=.16^{*}$ for modularity) than in the total sample. The second, internationalonly model yielded coefficients of $\beta=.48^{* * *}$ for EO and $\beta=.21^{* * *}$ for modularity. We controlled for firm size in both models. Differences in the indirect effects were much smaller and with no change in the direction or the level of significance. Despite the path differences between the German-only and the international-only model, we do not assume that the hypothesised effects differ substantially. Thus we conclude that nationality or national culture is of negligible significance.

\section{DISCUSSION}

This paper was motivated by the recently increasing attention paid to business model innovation and the concept's still immature theoretical basis, particularly for service firms that need dynamic capabilities to achieve BMI. 
As previous research already hints at a relation to the dynamic capabilityview, we aim to explain capabilities that drive BMI by drawing upon DCV. Research so far has not analysed how dynamic capabilities affect business model innovation. Thus this paper looks how dynamic capabilities such as entrepreneurial orientation and modularity jointly influence BMI in service firms.

\subsection{Contribution to Theory}

The results contribute to service research and to BMI research. First we enlarge the research body of BMI for service firms. Specifically, we show that service firms can take advantage of dynamic capabilities: each of the dynamic capabilities (EO and modularity) enhances BMI in service firms. We suggest that these important triggers serve as antecedents of BMI and should be included in future research on BMI. Moreover, we support previous BMI research that sees a link between dynamic capabilities and BMI. Further, uncertainty is not a thread but a trigger for BMI, especially when combined with EO. In line with Andries and Debackere (2013), we find that the capability to reconfigure resources and existing capabilities through modularization positively influences BMI but does not mediate the effect of technological uncertainty. Even though the risk-prone and creativity-oriented concept of EO is antithetical to the precise planning of modularization embedded in the service firms' process and product architectures, the combination of both does not lead to additional benefits for BMI. However, the central challenge for a successful implementation of BMI to use exploration capabilities such as EO and the ability to exploit new ideas through modularization was not supported by our data. Further we have shown that national culture shapes the impact of EO and modularity on BMI but does not differ significantly between Germany and all other nations.

\subsection{Limitations and Further Research}

Fundamentally, there is strong agreement among scholars that empirical research on dynamic capabilities should be intensified (Eriksson, 2014; McAdam et al., 2014). We believe that further research should analyse the connection between BMI and dynamic capability in particular. While qualitative studies allow a better understanding of processes and managerial and environmental issues, as well as reconfiguration mechanisms, further 
quantitative research could offer a more concrete identification of the factors involved, their nature, and their interactions (Easterby-Smith et al., 2009).

We did not find a combinative effect of EO and modularization - two somehow antithetical capabilities. Thus, the question arises whether other ambidextrous capabilities may foster BMI. Ambidexterity, the combination of two antithetical activities, is stressed as a driver of product innovation. Does this apply to BMI in service firms as well?

We processed our research with an international sample and controlled for country effect by differentiating a German-only and an international-only model. We did not find great differences between the two models. In contrast to research on the link between culture and firms' innovativeness (Taylor and Wilson, 2012; Černe et al., 2013), we cannot support a significant influence of national culture on BMI. Further research should be conducted to analyse whether our findings are industry-specific or whether the objects of innovation (products, processes, and business models) differ more fundamentally. Finally, not only does research on BMI lack a clear and accepted definition of the construct; established scales do not exist. We would like to encourage others to overcome this obstacle.

As the existence of time was outlined above as a constituent element of any form of dynamic concept, there is a strong requirement for further multiperiodical or longitudinal research to gain a better understanding of dynamic capabilities. Following previous research (Zahra et al., 2006), further investigations are needed regarding how dynamic capabilities differ between entrepreneurial, rather small firms and larger, saturated companies. This research gap gains even more importance for dynamic capabilities underlying BMI.

\subsection{Managerial Implications}

Backed by our results, the promotion of proactive and risky innovative behaviour of employees should be encouraged by managers. EO is a suitable means for contributing new ideas to firms' existing business models. If new ideas or concepts for creating and monetising value are born, they have to be implemented and "translated" into products before being marketed. However, we propose that EO and modularity be pursued consecutively and not simultaneously as hypothesized. BMI is most effective if exploration and exploitation occur together but supposedly one after another. 


\section{References}

Adner, R. and Helfat, C.E. (2003) 'Corporate effects and dynamic managerial capabilities', Strategic Management Journal, Vol. 24, No. 10, pp.1011-1025.

Al-Debei, M.M. and Avison, D. (2010) 'Developing a unified framework of the business model concept', European Journal of Information Systems, Vol. 19, No. 3, pp.359-376.

Amit, R. and Zott, C. (2012) 'Creating Value Through Business Model Innovation', MIT Sloan Management Review, Vol. 53, No. 3, pp.41-49.

Amit, R. and Zott, C. (2001) 'Value Creation In E-Business', Strategic Management Journal, Vol. 22, No. 6/7, pp.493.

Amit, R.H. and Zott, C. (2010) Business model innovation: Creating value in times of change. Available at SSRN: http://ssrn.com/abstract=1701660 or http://dx.doi.org/10.2139/ssrn.1701660

Anand, G., Ward, P.T., Tatikonda, M.V. and Schilling, D.A. (2009) 'Dynamic capabilities through continuous improvement infrastructure', Journal of Operations Management, Vol. 27, No. 6, pp.444-461.

Andries, P. and Debackere, K. (2013) 'Business Model Innovation: Propositions on the Appropriateness of Different Learning Approaches', Creativity \& Innovation Management, Vol. 22, No. 4, pp.337-358.

Aspara, J., Hietanen, J. and Tikkanen, H. (2010) 'Business model innovation vs replication: financial performance implications of strategic emphases', Journal of Strategic Marketing, Vol. 18, No. 1, pp.39-56.

Bagozzi, R.P. (1981) 'Evaluating Structural Equation Models with Unobservable Variables and Measurement Error - a Comment', Journal of Marketing Research, Vol. 18, No. 3, pp.375-381.

Bagozzi, R.P. and Yi, Y. (2012) 'Specification, evaluation, and interpretation of structural equation models', Journal of the Academy of Marketing Science, Vol. 40, No. 1, pp.8-34.

Barreto, I. (2010) 'Dynamic Capabilities: A Review of Past Research and an Agenda for the Future', Journal of Management, Vol. 36, No. 1, pp.256-280.

Blecker, T. and Abdelkafi, N. (2006) Mass customization: state-of-the-art and challenges, Mass customization: challenges and solutions: Springer, 1-25.

Blyler, M. and Coff, R.W. (2003) 'Dynamic capabilities, social ties, and rent appropriation: ties that split pies', Strategic Management Journal, Vol. 24, No. 7, pp.677-686.

Bock, A.J., Opsahl, T., George, G. and Gann, D.M. (2012) 'The Effects of Culture and Structure on Strategic Flexibility during Business Model Innovation', Journal of Management Studies, Vol. 49, No. 2, pp.279-305. 
Bouncken, R.B. (2007) 'Kosten und Wirkungen von Personalentwicklung - Eine Konzeption mittels multivariater Datenanalyseverfahren', BFuP, Vol. 59, No. 1, pp.66-75.

Bouncken, R.B. and Koch, M. (2007) 'The role of innovation orientation: strategic antecedents and innovation consequences of innovation orientation', International Journal of Technology Intelligence and Planning, Vol. 3, No. 3, pp.213-232.

Bouncken, R.B., Koch, M. and Teichert, T. (2007) 'Innovation strategy explored: innovation orientation's strategy preconditions and market performance outcomes', Zeitschrift für Betriebswirtschaft, Vol. 77, No. 2, pp.19-43.

Bouncken, R.B., Pesch, R. and Gudergan, S.P. (2015) 'Strategic embeddedness of modularity in alliances: Innovation and performance implications', Journal of Business Research, Vol. 68, No. 4.

Bouncken, R.B., Plüschke, B.D., Pesch, R. and Kraus, S. (2014) 'Entrepreneurial orientation in vertical alliances: joint product innovation and learning from allies', Review of Managerial Science, Vol. doi: 10.1007/s11846-014-0150-8, No. (in press), pp.1-29.

Bucherer, E., Eisert, U. and Gassmann, O. (2012) 'Towards Systematic Business Model Innovation: Lessons from Product Innovation Management', Creativity \& Innovation Management, Vol. 21, No. 2, pp.183-198.

Buenstorf, G. (2005) 'Sequential Production, Modularity and Technological Change', Structural Change and Economic Dynamics, Vol. 16, No. 2, pp.221-241.

Byrne, B.M. (2012) Structural equation modeling with Mplus: Basic concepts, applications, and programming, Routledge.

Campagnolo, D. and Camuffo, A. (2010) 'The Concept of Modularity in Management Studies: A Literature Review', International Journal of Management Reviews, Vol. 12, No. 3, pp.259-283.

Cautela, C., Pisano, P. and Pironti, M. (2014) 'The emergence of new networked business models from technology innovation: an analysis of 3-D printing design enterprises', International Entrepreneurship and Management Journal, Vol. 10, No. 3, pp.487-501.

Cavin, S. and Lohse, N. (2014) Multi-level skill-based allocation methodology for evolvable assembly systems. Paper presented at 2014 12th IEEE International Conference on Industrial Informatics (INDIN).

Černe, M., Jaklič, M. and Škerlavaj, M. (2013) 'Decoupling management and technological innovations: Resolving the individualism-collectivism controversy', Journal of International Management, Vol. 19, No. 2, pp.103-117.

Chen, J.-S., Kerr, D., Tsang, S.-S. and Sung, Y.C. (2015) 'Co-production of service innovations through dynamic capability enhancement', Service Industries Journal, Vol. 35, No. 1/2, pp.96-114.

Chesbrough, H. (2010) 'Business Model Innovation: Opportunities and Barriers', Long Range Planning, Vol. 43, No. 2-3, pp.354-363. 
Chesbrough, H. and Rosenbloom, R.S. (2002) 'The role of the business model in capturing value from innovation: evidence from Xerox Corporation's technology spin-off companies', Industrial \& Corporate Change, Vol. 11, No. 3, pp.529-555.

Clauß, T., Laudien, S.M. and Daxböck, B. (2014) 'Service-dominant logic and the business model concept: toward a conceptual integration', International Journal of Entrepreneurship and Innovation Management, Vol. 18, No. 4, pp.266-288.

Conrad, N.D., Banisch, R. and Schütte, C. (2014) Modularity of Directed Networks: Cycle Decomposition Approach, arXiv preprint arXiv:1407.8039.

Coulthard, M. (2007) 'The Role Of Entrepreneurial Orientation On Firm Performance And The Potential Influence Of Relational Dynamism', Journal of Global Business and Technology, Vol. 3, No. 1, pp.29-39.

Cronbach, L.J. (1951) 'Coefficient alpha and the internal structure of tests', psychometrika, Vol. 16, No. 3, pp.297-334.

Dixon, S., Meyer, K. and Day, M. (2014) 'Building Dynamic Capabilities of Adaptation and Innovation: A Study of Micro-Foundations in a Transition Economy', Long Range Planning, Vol. 47, No. 4, pp.186-205.

Drnevich, P.L. and Kriauciunas, A.P. (2011) 'Clarifying the conditions and limits of the contributions of ordinary and dynamic capabilities to relative firm performance', Strategic Management Journal, Vol. 32, No. 3, pp.254-279.

Easterby-Smith, M., Lyles, M.A. and Peteraf, M.A. (2009) 'Dynamic Capabilities: Current Debates and Future Directions', British Journal of Management, Vol. 20, No. Issue Supplement s1, pp.S1-S8.

Eggers, F., Kraus, S., Hughes, M., Laraway, S. and Snycerski, S. (2013) 'Implications of customer and entrepreneurial orientations for SME growth', Management Decision, Vol. 51, No. 3.

Eisenhardt, K.M. and Martin, J.A. (2000) 'Dynamic Capabilities: What Are They?', Strategic Management Journal, Vol. 21, No. 10/11, pp.1105.

Ellis, S., Sagiv, T. and Drori, I. (2014) 'Exploration-exploitation dilemmas of venture capital funds: the role of organisational slack and horizons', International Journal of Entrepreneurial Venturing, Vol. 6, No. 3, pp.220-241.

ElMaraghy, H.A. (2005) 'Flexible and reconfigurable manufacturing systems paradigms', International journal of flexible manufacturing systems, Vol. 17, No. 4, pp.261-276.

Eriksson, T. (2014) 'Processes, antecedents and outcomes of dynamic capabilities', Scandinavian Journal of Management, Vol. 30, No. 1, pp.65-82.

Ethiraj, S.K. and Levinthal, D. (2004) 'Modularity and innovation in complex systems', Management Science, Vol. 50, No. 2, pp.159-173.

Ethiraj, S.K., Levinthal, D. and Roy, R.R. (2008) 'The Dual Role of Modularity: Innovation and Imitation', Management Science, Vol. 54, No. 5, pp.939-955.

Euchner, J. and Ganguly, A. (2014) 'Business Model Innovation in Practice', Research Technology Management, Vol. 57, No. 6, pp.33-39. 
Fornell, C. and Larcker, D.F. (1981) 'Structural equation models with unobservable variables and measurement error: Algebra and statistics', Journal of marketing research, Vol. 18, No. 3, pp.382-388.

Gremyr, I., Löfberg, N. and Witell, L. (2010) 'Service innovations in manufacturing firms', Managing Service Quality, Vol. 20, No. 2, pp.161-175.

Grönroos, C. and Ojasalo, K. (2004) 'Service productivity: Towards a conceptualization of the transformation of inputs into economic results in services', Journal of Business Research, Vol. 57, No. 4, pp.414-423.

Guangping, W., Wenyu, D. and Nan, Z. (2013) Dynamic Capabilities, External Collaboration, And Firm Performance: A Conceptual Model. Paper presented at AMA Summer Educators' Conference Proceedings.

Guo, H., Zhao, J. and Tang, J. (2013) 'The role of top managers' human and social capital in business model innovation', Chinese Management Studies, Vol. 7, No. 3, pp.447-469.

Habtay, S.R. and Holmén, M. (2014) 'Incumbents' responses to disruptive business model innovation: the moderating role of technology vs. market-driven innovation', International Journal of Entrepreneurship \& Innovation Management, Vol. 18, No. 4, pp.289-309.

Hair, J.F., Black, B., Babin, B., Anderson, R.E. and Tatham, R.L. (2010) Multivariate Data Analysis, 7th edn ed, Upper Saddle River, NJ, Prentice Hall.

Hamel, G. and Prahalad, C.K. (1993) 'Strategy as Stretch and Leverage', Harvard Business Review, Vol., No. March-April, pp.74-84.

Hannan, M.T. and Freeman, J. (1984) 'Structural inertia and organizational change', American Sociological Review, Vol. 49, No. 2, pp.149-164.

Heij, C.V., Volberda, H.W. and Van Den Bosch, F.A.J. (2014) How Does Business Model Innovation Influence Firm Performance: The Moderating Effect Of Environmental Dynamism. Paper presented at Academy of Management Annual Meeting Proceedings.

Helfat, C. and Peteraf, M. (2003) 'The dynamic resource-based view: Capability lifecycles', Strategic Management Journal, Vol. 24, No. 10, pp.997-1010.

Helfat, C.E. (1997) 'Know-How And Asset Complementarity And Dynamic Capability Accumulation: The Case Of R\&D', Strategic Management Journal, Vol. 18, No. 5, pp.339-360.

Hipp, C. and Bouncken, R.B. (2009) 'Intellectual property protection in collaborative innovation activities within services', International Journal of Services Technology and Management, Vol. 12, No. 3, pp.273.

Huang, H.-C., Lai, M.-C., Kao, M.-C. and Chen, Y.-C. (2012) 'Target Costing, Business Model Innovation, and Firm Performance: An Empirical Analysis of Chinese Firms', Revue Canadienne des Sciences de l'Administration/Canadian Journal of Administrative Sciences, Vol. 29, No. 4, pp.322-335. 
Huang, H.-C., Lai, M.-C., Lin, L.-H. and Chen, C.-T. (2013) 'Overcoming organizational inertia to strengthen business model innovationAn open innovation perspective', Journal of Organizational Change Management, Vol. 26, No. 6, pp.977-1002.

Irava, W. and Moores, K. (2010) 'Resources supporting entrepreneurial orientation in multigenerational family firms', International Journal of Entrepreneurial Venturing, Vol. 2, No. 3/4, pp.222-245.

Jantunen, A., Puumalainen, K., Saarenketo, S. and Kyläheiko, K. (2005) 'Entrepreneurial orientation, dynamic capabilities and international performance', Journal of International Entrepreneurship, Vol. 3, No. 3, pp.223-243.

Kearney, A., Harrington, D. and Kelliher, F. (2014) 'Exploiting managerial capability for innovation in a micro-firm context', European Journal of Training and Development, Vol. 38, No. 1/2, pp.95-117.

Keh, H.T., Foo, M.D. and Lim, B.C. (2002) 'Opportunity evaluation under risky conditions: the cognitive processes of entrepreneurs', Entrepreneurship Theory and Practice, Vol. 27, No. 2, pp.125-148.

Kindström, D. (2010) 'Towards a service-based business model-Key aspects for future competitive advantage', European Management Journal, Vol. 28, No. 6, pp.479-490.

Kodama, F. (2004) 'Measuring emerging categories of innovation: Modularity and business model', Technological Forecasting and Social Change, Vol. 71, No. 6, pp.623-633.

Kraus, S. (2013) 'The role of entrepreneurial orientation in service firms: empirical evidence from Austria', Service Industries Journal, Vol. 33, No. 5, pp.427-444.

Kraus, S., Rigtering, J.C., Hughes, M. and Hosman, V. (2012) 'Entrepreneurial orientation and the business performance of SMEs: a quantitative study from the Netherlands', Review of Managerial Science, Vol. 6, No. 2, pp.161-182.

Lambert, S.C. and Davidson, R.A. (2013) 'Applications of the business model in studies of enterprise success, innovation and classification: An analysis of empirical research from 1996 to 2010', European Management Journal, Vol. 31, No. 6, pp.668-681.

Lau, A.K.W. and Yam, R.C.M. (2005) 'A case study of product modularization on supply chain design and coordination in Hong Kong and China', Journal of Manufacturing Technology Management, Vol. 16, No. 4, pp.432-446.

Lecocq, X., Demil, B. and Ventura, J. (2010) 'Business models as a research program in strategic management: an appraisal based on Lakatos', M@ n@ gement, Vol. 13, No. 4, pp.214-225.

Lewis, M.W., Welsh, M.A., Dehler, G.E. and Green, S.H. (2002) 'Product Development Tensions: Exploring Contrasting Styles of Project Management', Academy of Management Journal, Vol. 45, No. 3, pp.546-564. 
López, S.V. (2005) 'Competitive advantage and strategy formulation: The key role of dynamic capabilities', Management Decision, Vol. 43, No. 5, pp.661-669.

Lovelock, C. and Gummesson, E. (2004) 'Whither services marketing? In search of a new paradigm and fresh perspectives', Journal of service research, Vol. 7, No. 1, pp.20-41.

Lumpkin, G.T. and Dess, G.G. (1996) 'Clarifying the entrepreneurial orientation construct and linking it to performance', Academy of Management Review, Vol. 21, No. 1, pp.135-172.

Makkonen, H., Pohjola, M., Olkkonen, R. and Koponen, A. (2014) 'Dynamic capabilities and firm performance in a financial crisis', Journal of Business Research, Vol. 67, No. 1, pp.2707-2719.

Markides, C.C. (2013) 'Business model innovation: What can the ambidexterity literature teach us?', Academy of Management Perspectives, Vol. 27, No. 4, pp.313-323.

McAdam, R., Reid, R. and Shevlin, M. (2014) 'Determinants for innovation implementation at SME and inter SME levels within peripheral regions', International Journal of Entrepreneurial Behaviour \& Research, Vol. 20, No. 1, pp.66-90.

McGrath, R.G. (2010) 'Business models: a discovery driven approach', Long range planning, Vol. 43, No. 2, pp.247-261.

Mikkola, J.H. (2007) 'Management of product architecture modularity for mass customization: modeling and theoretical considerations', Engineering Management, IEEE Transactions on, Vol. 54, No. 1, pp.57-69.

Miller, T.D. and Elgard, P. (1998) Defining modules, modularity and modularization. Paper presented at Proceedings of the 13th IPS Research Seminar, Fuglsoe.

Mitchell, D.W. and Coles, C.B. (2004) 'Business model innovation breakthrough moves', Journal of Business Strategy, Vol. 25, No. 1, pp.16-26.

Morris, M.H., Kuratko, D.F. and Covin, J.G. (2008) Corporate Entrepreneurship \& Innovation, 2nd ed, Mason, OH, USA, Thomson Higher Education.

Mowery, D.C., Oxely, J.E. and Silverman, B.S. (1996) 'Strategic Alliances and Interfirm Knowledge Transfer', Strategic Management Journal, Vol. 17, No. Special Issue: Knowledge and the Firm, pp.77-91.

Muthén, L.K. and Muthén, B.O. (2012) 'Mplus', The comprehensive modelling program for applied researchers: User's guide, Vol. 5, No.

Nair, S., Paulose, H., Palacios, M. and Tafur, J. (2013) 'Service orientation: effectuating business model innovation', Service Industries Journal, Vol. 33, No. 9/10, pp.958-975.

Nunnally, J.C. (1978) Psychometric Theory, 2nd ed, New York, McGraw-Hill Inc.

O'Connor, A. and Yamin, S. (2011) 'Innovation and entrepreneurship: managing the paradox of purpose in business model innovation', International Journal of Learning and Intellectual Capital, Vol. 8, No. 3, pp.239-255. 
O'Reilly, C.A. and Tushman, M. (2009) Ambidexterity as a Dynamic Capability: Resolving the Innovator's Dilemma. Rochester: Social Science Research Network.

Onetti, A., Zucchella, A., Jones, M. and McDougall-Covin, P. (2012) 'Internationalization, innovation and entrepreneurship: business models for new technology-based firms', Journal of Management \& Governance, Vol. 16, No. 3, pp.337-368.

Osterwalder, A., Pigneur, Y. and Tucci, C.L. (2005) 'Clarifying business models: Origins, present, and future of the concept', Communications of the association for Information Systems, Vol. 16, No. 1, pp.1.

Ozman, M. (2011) 'Modularity, Industry Life Cycle and Open Innovation', Journal of Technology Management \& Innovation, Vol. 6, No. 1, pp.26-37.

Papinniemi, J. (1999) 'Creating a Model of Process Innovation for Reengineering of Business and Manufacturing', International Journal of Production Economics, Vol. 60-61, No. 3, pp.95-101.

Parente, R.C., Baack, D.W. and Hahn, E.D. (2011) 'The effect of supply chain integration, modular production, and cultural distance on new product development: A dynamic capabilities approach', Journal of International Management, Vol. 17, No. 4, pp.278-290.

Persson, M. and Åhlström, P. (2013) 'Product modularisation and organisational coordination', International Journal of Automotive Technology \& Management, Vol. 13, No. 1, pp.55-74.

Pisano, G.P. and Teece, D.J. (2007) 'How to Capture Value from Innovation: Shaping Intellectual Property And Industry Architecture', California Management Review, Vol. 50, No. 1, pp.278-296.

Podsakoff, P.M., MacKenzie, S.B., Lee, J.-Y. and Podsakoff, N.P. (2003) 'Common method biases in behavioral research: A critical review of the literature and recommended remedies', Journal of Applied Psychology, Vol. 88, No. 5, pp.879903.

Rajala, R., Westerlund, M. and Möller, K. (2012) 'Strategic flexibility in open innovation - designing business models for open source software', European Journal of Marketing, Vol. 46, No. 10, pp.1368-1388.

Rauch, A., Wiklund, J., Lumpkin, G. and Frese, M. (2009) 'Entrepreneurial Orientation and Business Performance: An Assessment of Past Research and Suggestions for the Future', Entrepreneurship: Theory \& Practice, Vol. 33, No. 3, pp.761-787.

Ravishankar, M.N. and Pan, S.L. (2013) 'Examining the influence of modularity and knowledge management (KM) on dynamic capabilities: Insights from a call center', International Journal of Information Management, Vol. 33, No. 1, pp.147159 . 
Ro, Y.K., Liker, J.K. and Fixson, S.K. (2007) 'Modularity as a strategy for supply chain coordination: The case of US auto', Engineering Management, IEEE Transactions on, Vol. 54, No. 1, pp.172-189.

Roaldsen, I. (2014) 'Dynamic capabilities as drivers of business model innovation from the perspective of SMEs in mature industries', International Journal of Entrepreneurship \& Innovation Management, Vol. 18, No. 4, pp.349-364.

Rowley, J., Baregheh, A. and Sambrook, S. (2011) 'Towards an innovation-type mapping tool', Management Decision, Vol. 49, No. 1, pp.73-86.

Sánchez, P. and Ricart, J.E. (2010) 'Business model innovation and sources of value creation in low-income markets', European Management Review, Vol. 7, No. 3, pp.138-154.

Sanchez, R. and Mahoney, J.T. (1996) 'Modularity, flexibility, and knowledge management in product and organization design', Strategic management journal, Vol. 17, No. S2, pp.63-76.

Sanchez, R. and Mahoney, J.T. (1996) 'Modularity, flexibility, and knowledge management in product and organization design', Strategic Management Journal, Vol. 17, No., pp.63-76.

Santos, J., Spector, B. and Van der Heyden, L. (2009) Toward a Theory of Business Model Innovation within Incumbent Firms, INSEAD Working Papers Collection.

Scannella, E. (2010) 'Transaction Costs, Standardization and Modularity in Credit Risk Transfer Market', International Journal of Economics and Business Modeling, Vol. 1, No. 2, pp.21-28.

Schilling, M.A. (2000) 'Toward a general modular systems theory and its application to interfirm product modularity', Academy of management review, Vol. 25, No. 2, pp.312-334.

Schindehutte, M., Morris, M.H. and Kocak, A. (2008) 'Understanding MarketDriving Behavior: The Role of Entrepreneurship', Journal of Small Business Management, Vol. 46, No. 1, pp.4-26.

Schneider, S. and Spieth, P. (2013) 'Business Model Innovation: Towards An Integrated Future Research Agenda', International Journal of Innovation Management, Vol. 17, No. 1, pp.34.

Seddon, P.B., Lewis, G.P., Freeman, P. and Shanks, G. (2004) 'The case for viewing business models as abstractions of strategy', The Communications of the Association for Information Systems, Vol. 13, No. 1, pp.64.

Seelos, C. and Mair, J. (2007) 'Profitable business models and market creation in the context of deep poverty: a strategic view', The academy of management perspectives, Vol. 21, No. 4, pp.49-63.

Siguaw, J.A., Simpson, P.M. and Enz, C.A. (2006) 'Conceptualizing Innovation Orientation: A Framework for Study and Integration of Innovation Research', Journal of Product Innovation Management, Vol. 23, No. 6, pp.556-574. 
Simmons, G., Palmer, M. and Truong, Y. (2013) 'Inscribing value on business model innovations: Insights from industrial projects commercializing disruptive digital innovations', Industrial Marketing Management, Vol. 42, No. 5, pp.744-754.

Singh, D., Oberoi, J.S. and Ahuja, I.S. (2013) 'An empirical investigation of dynamic capabilities in managing strategic flexibility in manufacturing organizations', Management Decision, Vol. 51, No. 7, pp.1442-1461.

Sirmon, D.G., Hitt, M.A. and Ireland, R.D. (2007) 'Managing firm resources in dynamic environments to create value: Looking inside the black box', Academy of management review, Vol. 32, No. 1, pp.273-292.

Spieth, P., Schneckenberg, D. and Ricart, J.E. (2014) 'Business model innovation state of the art and future challenges for the field', R\&D Management, Vol. 44, No. 3, pp.237-247.

Srinivasan, S.K. (2011) 'Harvard Business Review on Business Model Innovation (2010), Harvard Business School Publishing: Boston, MA', Vilakshan: The XIMB Journal of Management, Vol. 7, No. 3, pp.139-142.

Taylor, M.Z. and Wilson, S. (2012) 'Does culture still matter?: The effects of individualism on national innovation rates', Journal of Business Venturing, Vol. 27, No. 2, pp.234-247.

Teece, D. and Augier, M. (2009) 'The foundations of dynamic capabilities', Dynamic Capabilities \& Strategic Management-Organizing for Innovation and Growth, Oxford University Press, Oxford, Vol. 27, No. 2, pp.82-112.

Teece, D. and Pisano, G. (1994) 'The dynamic capabilities of firms: an introduction', Industrial and corporate change, Vol. 3, No. 3, pp.537-556.

Teece, D., Pisano, G. and Shuen, A. (1997) 'Dynamic capabilities and strategic management', Strategic Management Journal, Vol. 18, No. 7, pp.509-533.

Teece, D.J. (2010) 'Business models, business strategy and innovation', Long range planning, Vol. 43, No. 2, pp.172-194.

Teece, D.J. (2010) 'Business Models, Business Strategy and Innovation', Long Range Planning, Vol. 43, No. 2/3, pp.172-194.

Teece, D.J. (2007) 'Explicating dynamic capabilities: the nature and microfoundations of (sustainable) enterprise performance', Strategic Management Journal, Vol. 28, No. 13, pp.1319-1350.

Teece, D.J. (2000) 'Firm capabilities and economic development: Implications for the newly industrializing economies', Technology, learning and innovation: Experiences of newly industrializing economies, Vol. 44, No. 3, pp.105-128.

Tsvetkova, A. and Gustafsson, M. (2012) 'Business models for industrial ecosystems: a modular approach', Journal of Cleaner Production, Vol. 29-30, No. 0, pp.246254.

Van Liere, D. and Koppius, O. (2007) 'Network Horizon And Obtaining A Favorable Network Position', Communications of the ACM, Vol. 50, No. 6, pp.35-35. 
van Liere, D.W., Hagdorn, L., Hoogeweegen, M.R. and Vervest, P.H.M. (2004) 'Embedded coordination in a business network', Journal of Information Technology (Palgrave Macmillan), Vol. 19, No. 4, pp.261-269.

Van Riel, A.C.R., Semeijn, J., Hammedi, W. and Henseler, J. (2011) 'Technologybased service proposal screening and decision-making effectiveness', Management Decision, Vol. 49, No. 5, pp.762-783.

Vargo, S.L. and Lusch, R.F. (2008) 'From goods to service (s): Divergences and convergences of logics', Industrial Marketing Management, Vol. 37, No. 3, pp.254-259.

Venkatraman, N. and Ramanujam, V. (1986) 'Measurement of business performance in strategy research: A comparison of approaches', Academy of management review, Vol. 11, No. 4, pp.801-814.

Vermeulen, C. (2013) A Conceptualization Linking Intellectual Capital, Dynamic Capabilities and Performance of Knowledge-Intensive Service Firms. Paper presented at Proceedings of the International Conference on Intellectual Capital, Knowledge Management \& Organizational Learning.

Vij, S. and Bedi, H.S. (2012) 'Relationship Between Entrepreneurial Orientation and Business Performance: A Review of Literature', IUP Journal of Business Strategy, Vol. 9, No. 3, pp.17-31.

Vorhies, D.W., Foley, L.M., Bush, V.D. and Clark, M. (2007) Market-Based Dynamic Capabilities And Firm Performance. Paper presented at AMA Winter Educators' Conference Proceedings.

Voss, C.A. and Hsuan, J. (2009) 'Service Architecture and Modularity*', Decision Sciences, Vol. 40, No. 3, pp.541-569.

Wang, C.L. and Ahmed, P.K. (2007) 'Dynamic capabilities: A review and research agenda', International Journal of Management Reviews, Vol. 9, No. 1, pp.31-51.

Weng, Z.K. (1999) 'Risk-Pooling Over Demand Uncertainty in the Presence of Product Modularity', International Journal of Production Economics, Vol. 62, No. 1-2, pp.75-85.

Winter, S.G. (2003) 'Understanding Dynamic Capabilities', Strategic Management Journal, Vol. 24, No. 10, pp.991-995.

Witell, L. and Löfgren, M. (2013) 'From service for free to service for fee: business model innovation in manufacturing firms', Journal of Service Management, Vol. 24, No. 5, pp.4-4.

Worren, N., Moore, K. and Cardona, P. (2002) 'Modularity, strategic flexibility, and firm performance: a study of the home appliance industry', Strategic management journal, Vol. 23, No. 12, pp.1123-1140.

York, J.G. and Venkataraman, S. (2010) 'The entrepreneur-environment nexus: Uncertainty, innovation, and allocation', Journal of Business Venturing, Vol. 25, No. 5, pp.449-463. 
Zahra, S.A., Sapienza, H.J. and Davidsson, P. (2006) 'Entrepreneurship and Dynamic Capabilities: A Review, Model and Research Agenda', Journal of Management Studies, Vol. 43, No. 4, pp.917-955.

Zeithaml, V., Parasuraman, A. and Berry, L.L. (1985) 'Problems and strategies in services marketing', Journal of Marketing, Vol. 49, No. Spring, pp.33-46.

Zollo, M. and Winter, S. (2002) 'Deliberate learning and the evolution of dynamic capabilities', Organization Science, Vol. 13, No. 2, pp.339-351.

Zott, C. (2003) 'Dynamic Capabilities And The Emergence Of Intraindustry Differential Firm Performance: Insights From A Simulation Study', Strategic Management Journal, Vol. 24, No. 2, pp.97.

Zott, C. and Amit, R. (2010) 'Business model design: an activity system perspective', Long range planning, Vol. 43, No. 2, pp.216-226.

Zott, C., Amit, R. and Massa, L. (2011) 'The business model: recent developments and future research', Journal of management, Vol. 37, No. 4, pp.1019-1042. 
Table 1: Classification of DCs

\begin{tabular}{|c|c|c|c|c|}
\hline Author & Stream & Definition & Central focus & $\begin{array}{l}\text { Trig- } \\
\text { gers }\end{array}$ \\
\hline 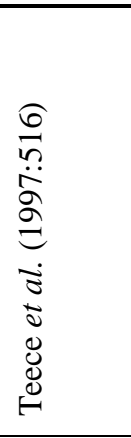 & $\begin{array}{l}\text { Teece and } \\
\text { Pisano, } \\
\text { 1994; } \\
\text { Teece et } \\
\text { al., 1997; } \\
\text { Helfat, } \\
\text { 1997; } \\
\text { Helfat and } \\
\text { Peteraf, } \\
\text { 2003; Zott, } \\
\text { 2003 }\end{array}$ & $\begin{array}{l}\text { We define dynamic } \\
\text { capabilities as the firm's } \\
\text { ability to integrate, build, and } \\
\text { reconfigure internal and } \\
\text { external competences to } \\
\text { address rapidly changing } \\
\text { environments. }\end{array}$ & $\begin{array}{l}\text { Competences and } \\
\text { capabilities, environment } \\
\text { changes } \\
\text { ABILITY }\end{array}$ & 를 \\
\hline 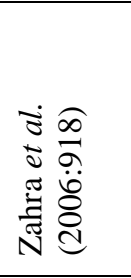 & $\begin{array}{l}\text { Zahra et } \\
\text { al., } 2006\end{array}$ & $\begin{array}{l}\text { Dynamic capabilities, which } \\
\text { we define as the abilities to } \\
\text { reconfigure a firm's } \\
\text { resources and routines in the } \\
\text { manner envisioned and } \\
\text { deemed appropriate by its } \\
\text { principal decision-maker(s). }\end{array}$ & $\begin{array}{l}\text { Ability and willingness for } \\
\text { opportunity detecting and } \\
\text { exploiting capabilities } \\
\text { ABILITY BEHIND }\end{array}$ & 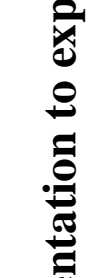 \\
\hline 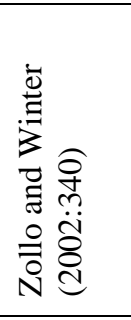 & $\begin{array}{l}\text { Zollo and } \\
\text { Winter, } \\
2002 ; \\
\text { Winter, } \\
\text { 2003; } \\
\text { Anand } \text { et } \\
\text { al., } 2009\end{array}$ & $\begin{array}{l}\text { A dynamic capability is a } \\
\text { learned and stable pattern of } \\
\text { collective activity through } \\
\text { which the organization } \\
\text { systematically generates and } \\
\text { modifies its operating routines } \\
\text { in pursuit of improved } \\
\text { effectiveness. }\end{array}$ & $\begin{array}{l}\text { Second-order routines, } \\
\text { systematical approach, } \\
\text { COLLECTIVE } \\
\text { ACTIVITY }\end{array}$ & $\frac{\bar{d}}{0}$ \\
\hline 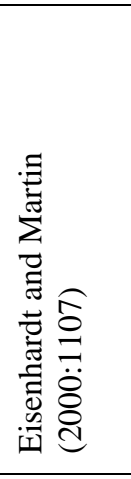 & $\begin{array}{l}\text { Eisenhardt } \\
\text { and } \\
\text { Martin, } \\
\text { 2000; } \\
\text { Blyler and } \\
\text { Coff, } 2003\end{array}$ & $\begin{array}{l}\text { The firm's processes that use } \\
\text { resources - specifically the } \\
\text { processes to integrate, } \\
\text { reconfigure, gain, and release } \\
\text { resources - to match and even } \\
\text { create market change. } \\
\text { Dynamic capabilities are thus } \\
\text { the organizational and } \\
\text { strategic routines by which } \\
\text { firms achieve new resource } \\
\text { configurations as markets } \\
\text { emerge [...]. }\end{array}$ & $\begin{array}{l}\text { Resource recombination, } \\
\text { organizational and } \\
\text { strategic routines, market } \\
\text { changes } \\
\text { PROCESSES }\end{array}$ & $\underset{0}{0}$ \\
\hline
\end{tabular}


Table 1: Continued

\begin{tabular}{|c|c|c|c|c|}
\hline 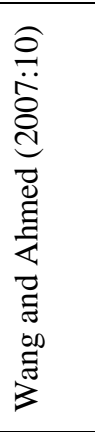 & $\begin{array}{l}\text { Wang and } \\
\text { Ahmed, } \\
2007\end{array}$ & $\begin{array}{l}\text { Dynamic capabilities as a } \\
\text { firm's behavioural } \\
\text { orientation to constantly } \\
\text { integrate, reconfigure, renew } \\
\text { and recreate its resources and } \\
\text { capabilities, and most } \\
\text { importantly, upgrade and } \\
\text { reconstruct its core } \\
\text { capabilities in response to the } \\
\text { changing environment to } \\
\text { attain competitive advantage. }\end{array}$ & $\begin{array}{l}\text { Resource recombination, } \\
\text { systematical approach, } \\
\text { third-order processes, } \\
\text { environment changes } \\
\text { BEHAVIORAL } \\
\text { ORIENTATION AND } \\
\text { OPERATIONS }\end{array}$ & \\
\hline 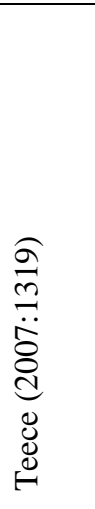 & $\begin{array}{l}\text { Teece, } \\
2000 \\
\text { Teece, } \\
2007\end{array}$ & $\begin{array}{l}\text { Dynamic capabilities can be } \\
\text { disaggregated into the } \\
\text { capacity (a) to sense and } \\
\text { shape opportunities and } \\
\text { threats, (b) to seize } \\
\text { opportunities, and (c) to } \\
\text { maintain competitiveness } \\
\text { through enhancing, } \\
\text { combining, protecting, and, } \\
\text { when necessary, } \\
\text { reconfiguring the business } \\
\text { enterprise's intangible and } \\
\text { tangible assets. }\end{array}$ & $\begin{array}{l}\text { Resource recombination, } \\
\text { opportunity detecting and } \\
\text { exploiting capabilities, } \\
\text { environment changes } \\
\text { STRATEGIC } \\
\text { CAPACITY AND } \\
\text { RECOMBINATION }\end{array}$ & $\frac{\sqrt{0}}{\frac{0}{0}}$ \\
\hline 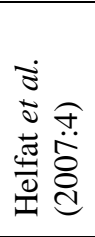 & $\begin{array}{l}\text { Adner and } \\
\text { Helfat, } \\
2003 \text {; } \\
\text { Easterby- } \\
\text { Smith et } \\
\text { al., } 2009\end{array}$ & $\begin{array}{l}\text { A dynamic capability is the } \\
\text { capacity of an organization to } \\
\text { purposefully create, extend, or } \\
\text { modify its resource base. }\end{array}$ & $\begin{array}{l}\text { CAPACITY FOR } \\
\text { CREATION AND } \\
\text { RECONFIGURATION }\end{array}$ & 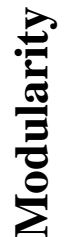 \\
\hline 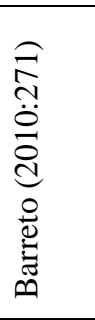 & $\begin{array}{l}\text { Barreto, } \\
2010\end{array}$ & $\begin{array}{l}\text { A dynamic capability is the } \\
\text { firm's potential to } \\
\text { systematically solve problems, } \\
\text { formed by its propensity to } \\
\text { sense opportunities and } \\
\text { threats, to make timely and } \\
\text { market-oriented decisions, and } \\
\text { to change its resource base. }\end{array}$ & $\begin{array}{l}\text { Resource recombination, } \\
\text { Systematical approach, } \\
\text { opportunity/threat } \\
\text { detecting and exploiting } \\
\text { capabilities, } \\
\text { STRATEGIC ORIEN- } \\
\text { TATION AND } \\
\text { RECOMBINATION }\end{array}$ & \\
\hline
\end{tabular}


Figure 1: Proposed research model (with hypothesized direction of effects)

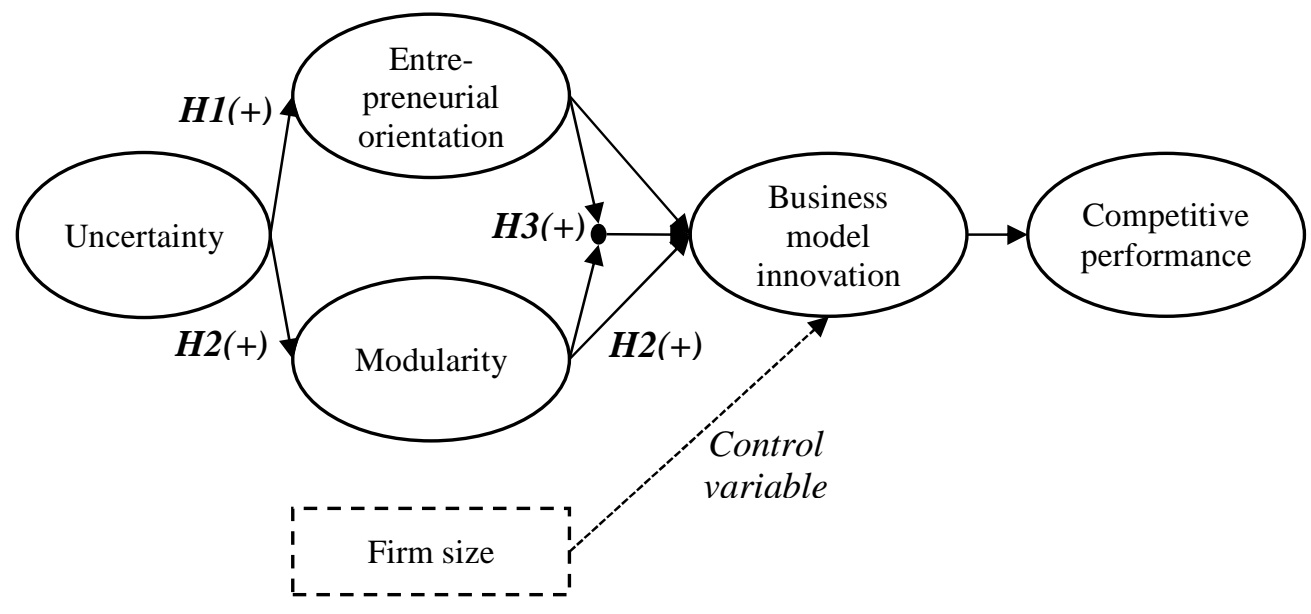

Table 2: Descriptive sample statistics ( $\mathrm{n}=299)$

\begin{tabular}{rccc}
\hline & Mean & SD & Median \\
\hline Firm characteristics & & & \\
Employees & 219 & 618 & 48 \\
Year established & 1981 & 30 & 1990 \\
Share of exports (in \%) & 44 & 31 & 43 \\
Turnover (p. a. in mill. €) & 33.9 & 55.7 & 8.0 \\
Rate of return (in \%) & 17.5 & 14.0 & 14.8 \\
\hline Respondents' characteristics & & & \\
Share of males (\%) & 84 & & \\
Tenure (years) & 6.8 & 6.5 & 4.2 \\
\% Top management/owner & 35 & & \\
\% Middle management & 29 & & \\
\% Lower management & 10 & & \\
\hline
\end{tabular}


Table 3: Origin of surveyed service firms $(n=299)$

\begin{tabular}{lcc}
\hline & abs. & rel. $(\boldsymbol{\%})$ \\
\hline Germany & 112 & 38 \\
EU (except GER) & 92 & 31 \\
USA & 12 & 4 \\
Asia & 55 & 18 \\
Others & 28 & 9 \\
\hline Sum & 299 & 100 \\
\hline
\end{tabular}

Table 4: Bivariate correlations $(n=299)$

\begin{tabular}{|c|c|c|c|c|c|c|c|c|c|c|c|}
\hline & & 1 & 2 & & 3 & & 4 & & 5 & & 6 \\
\hline 1 & Competitive performance & 1 & & & & & & & & & \\
\hline 2 & BMI & $.293^{* *}$ & 1 & & & & & & & & \\
\hline 3 & $\mathrm{EO}$ & $.219^{*}$ & .409 & $* * *$ & 1 & & & & & & \\
\hline 4 & Modularity & $.319^{* * *}$ & .476 & *** & .489 & $* * *$ & 1 & & & & \\
\hline 5 & Uncertainty & $.137^{\text {n.s. }}$ & .153 & * & .258 & $* *$ & .089 & n.s. & 1 & & \\
\hline 6 & Firm size & $.070^{\text {n.s. }}$ & .003 & n.s. & .048 & n.s. & .048 & n.s. & .008 & n.s. & 1 \\
\hline
\end{tabular}


Figure 2. Model results, path coefficients and significances $(n=264)$

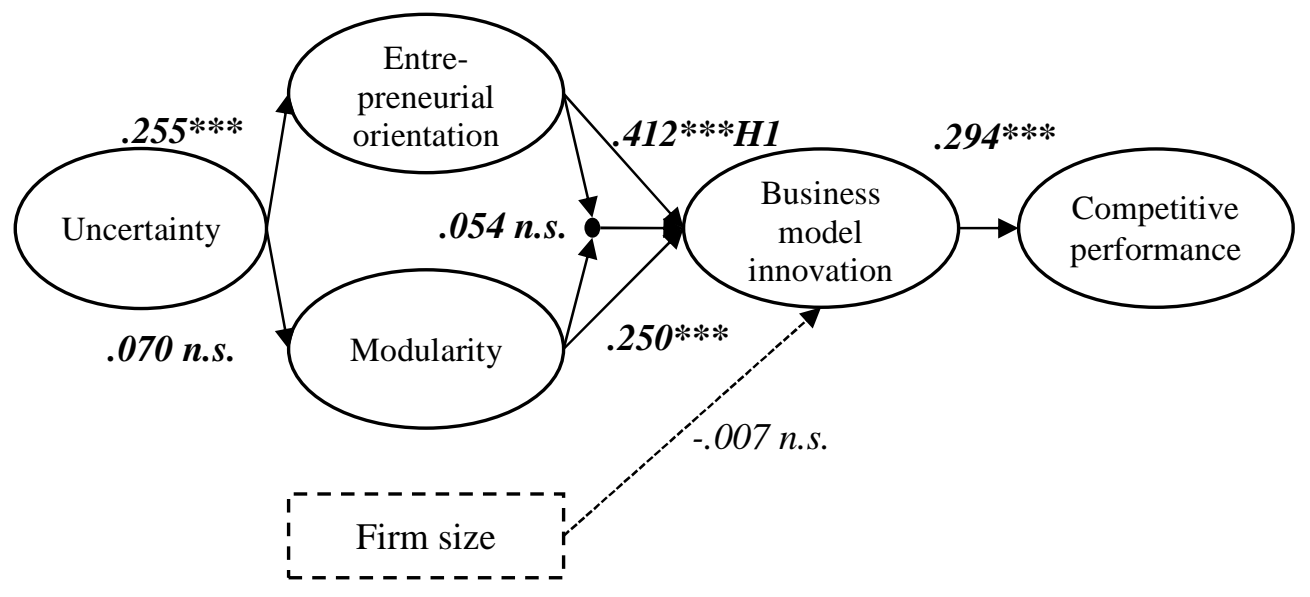

Table 5: Results of SEM for hypotheses 1 to $3(n=264)$

\begin{tabular}{|c|c|c|c|c|c|c|}
\hline $\begin{array}{l}\text { Hypo- } \\
\text { thesis }\end{array}$ & $\begin{array}{l}\text { Independent } \\
\text { variable }\end{array}$ & $\begin{array}{l}\text { Dependent } \\
\text { variable }\end{array}$ & Mediator & \multicolumn{2}{|c|}{ Effect size } & acc./rej. \\
\hline \multirow{2}{*}{$\mathrm{H} 1$} & $\begin{array}{l}\text { Entrepreneurial } \\
\text { orientation (EO) }\end{array}$ & $\begin{array}{l}\text { Business model } \\
\text { innovation }\end{array}$ & & .412 & $* * *$ & Accepted \\
\hline & Uncertainty & $\begin{array}{l}\text { Business model } \\
\text { innovation }\end{array}$ & EO & .105 & ** & Accepted \\
\hline \multirow{2}{*}{$\mathrm{H} 2$} & Modularity & $\begin{array}{l}\text { Business model } \\
\text { innovation }\end{array}$ & & .250 & ** & Accepted \\
\hline & Uncertainty & $\begin{array}{l}\text { Business model } \\
\text { innovation }\end{array}$ & $\begin{array}{l}\text { Modul- } \\
\text { arity }\end{array}$ & .017 & (n.s.) & Rejected \\
\hline H3 & $\begin{array}{l}\text { Interaction } \\
\text { term: } \\
\text { EO x } \\
\text { Modularity }\end{array}$ & $\begin{array}{l}\text { Business model } \\
\text { innovation }\end{array}$ & & .054 & (n.s.) & Rejected \\
\hline Control & Firm size & $\begin{array}{l}\text { Business model } \\
\text { innovation }\end{array}$ & & -.007 & & \\
\hline
\end{tabular}

Model-Fit: Chi $^{2} / d f=1.564 * * * ; C F I=.929 ;$ RMSEA=.046; SRMR=.070

Regression weights are significant at the level $p<.001^{* * *}, p<.01 * *$, and $p<.05^{*}$. 
Appendix 1: Results of a confirmatory factor analysis

\begin{tabular}{|c|c|c|c|c|c|c|c|}
\hline Construct & Items & $\begin{array}{l}\text { Standardized } \\
\text { factor } \\
\text { loadings }^{\mathrm{a}}\end{array}$ & $\begin{array}{l}\text { Indicator } \\
\text { reliability } \\
\quad \geq 0.4^{\mathrm{b}}\end{array}$ & $\begin{array}{l}\text { Cronbach's } \alpha \\
\geq 0.7^{\mathrm{c}}\end{array}$ & $\begin{array}{l}\text { Composite } \\
\text { reliability } \\
\quad \geq 0.6^{\mathrm{d}}\end{array}$ & $\mathrm{AVE} \geq 0.5^{\mathrm{e}}$ & $\begin{array}{l}\text { Fornell- } \\
\text { Larcker } \\
\quad<1^{\mathrm{e}}\end{array}$ \\
\hline \multirow{4}{*}{$\begin{array}{l}\text { Competitive } \\
\text { performance }\end{array}$} & Compared to its competitors, our company achieves... & & & \multirow{4}{*}{.733} & \multirow{4}{*}{.757} & \multirow{4}{*}{.514} & \multirow{4}{*}{.995} \\
\hline & ... higher sales. & .651 & .423 & & & & \\
\hline & ... a higher market share. & .895 & .801 & & & & \\
\hline & ... a higher profit margin. & .793 & .628 & & & & \\
\hline \multirow{6}{*}{$\begin{array}{l}\text { Business model } \\
\text { innovation }\end{array}$} & Our innovations (product, process, or business model)... & & & \multirow{6}{*}{.866} & \multirow{6}{*}{.868} & \multirow{6}{*}{.571} & \multirow{6}{*}{.920} \\
\hline & ... incorporate technology that is new to customers. & .766 & .587 & & & & \\
\hline & $\ldots$ offer benefits that are new to the customers. & .844 & .712 & & & & \\
\hline & ... introduce completely new features or functions. & .856 & .733 & & & & \\
\hline & $\ldots$ address new market segments. & .625 & .391 & & & & \\
\hline & ... comprise extensive changes to the design. & .659 & .434 & & & & \\
\hline \multirow{3}{*}{$\begin{array}{l}\text { Entrepreneurial } \\
\text { orientation } \\
\text { (2nd order) }\end{array}$} & Risk-taking & .693 & .480 & \multirow{3}{*}{.865} & \multirow{3}{*}{.884} & \multirow{3}{*}{.721} & \multirow{3}{*}{.729} \\
\hline & Proactivity & .927 & .859 & & & & \\
\hline & Innovativeness & .907 & .823 & & & & \\
\hline \multirow{3}{*}{ Modularity } & $\begin{array}{l}\text { Standardized interfaces allow functional and physical } \\
\text { interactions between our core components. }\end{array}$ & .841 & .707 & \multirow{3}{*}{.754} & \multirow{3}{*}{.847} & \multirow{3}{*}{.651} & \multirow{3}{*}{.855} \\
\hline & $\begin{array}{l}\text { Standardized interfaces in the product architecture allow our } \\
\text { core components to be interchangeable. }\end{array}$ & .888 & .788 & & & & \\
\hline & $\begin{array}{l}\text { Our product architecture allows a flexible combination of core } \\
\text { components. }\end{array}$ & .675 & .455 & & & & \\
\hline \multirow{4}{*}{ Uncertainty } & In the development and introduction of innovations there is ver & gh uncertainty & ut... & \multirow{4}{*}{.799} & \multirow{4}{*}{.867} & \multirow{4}{*}{.689} & \multirow{4}{*}{.860} \\
\hline & ... staff's familiarity with the technology. & .755 & .570 & & & & \\
\hline & ... the technological feasibility. & .990 & .980 & & & & \\
\hline & ... the functionality of products. & .719 & .516 & & & & \\
\hline
\end{tabular}

${ }^{a}$ All factor loadings are significant (t>3.1; p<.001). ${ }^{b}$ Bagozzi and Baumgartner (1994). ${ }^{\mathrm{c} N u n n a l l y ~(1978) . ~}{ }^{\mathrm{d}}$ Bagozzi and Yi (1988). ${ }^{\mathrm{e}}$ Fornell and Larcker (1981). 